\title{
Milk fatty acid composition, rumen microbial population, and animal performances in response to diets rich in linoleic acid supplemented with chestnut or quebracho tannins in dairy ewes
}

\author{
A. Buccioni, ${ }^{*}$ M. Pauselli,† C. Viti, ${ }^{*}$ S. Minieri, ${ }^{*}$ G. Pallara, ${ }^{*}$ V. Roscini, $\dagger$ S. Rapaccini, ${ }^{*}$ M. Trabalza Marinucci, $\ddagger$ \\ P. Lupi, ${ }^{*}$ G. Conte, $\S$ and M. Mele§ \\ *Dipartimento di Scienze delle Produzioni Agro-alimentari e dell'Ambiente, University of Florence, Piazzale delle Cascine 18, 50144 Firenze, Italy \\ †Dipartimento di Scienze Agrarie Alimentari ed Ambientali, University of Perugia, Borgo XX Giugno 74, 06121 Perugia, Italy \\ ‡Dipartimento di Medicina Veterinaria, University of Perugia, Via S. Costanzo 4, 06126 Perugia, Italy \\ §Dipartimento di Scienze Agrarie, Alimentari e Agro-ambientali, University of Pisa, Via del Borghetto 80, 56124 Pisa, Italy
}

\section{ABSTRACT}

The aim of the study was to evaluate milk fatty acid (FA) profile, animal performance, and rumen microbial population in response to diets containing soybean oil supplemented or not with chestnut and quebracho tannins in dairy ewes. Eighteen Comisana ewes at $122 \pm 6$ $\mathrm{d}$ in milking were allotted into 3 experimental groups. Diets were characterized by chopped grass hay administered ad libitum and by $800 \mathrm{~g} / \mathrm{head}$ and day of 3 experimental concentrates containing $84.5 \mathrm{~g}$ of soybean oil $/ \mathrm{kg}$ of dry matter $(\mathrm{DM})$ and $52.8 \mathrm{~g} / \mathrm{kg}$ of $\mathrm{DM}$ of bentonite (control diet), chestnut tannin extract (CHT diet), or quebracho tannin extract (QUE diet). The trial lasted 4 wk. Milk yield was recorded daily, and milk composition and blood parameters were analyzed weekly. At the end of the experiment, samples of rumen fluid were collected to analyze $\mathrm{pH}$, volatile fatty acid profile, and the relative proportions of Butyrivibrio fibrisolvens and Butyrivibrio proteoclasticus in the rumen microbial population. Hepatic functionality, milk yield, and gross composition were not affected by tannin extracts, whereas milk FA composition was characterized by significant changes in the concentration of linoleic acid (CHT $+2.77 \%$ and $\mathrm{QUE}+9.23 \%)$, vaccenic acid $(\mathrm{CHT}+7.07 \%$ and $\mathrm{QUE}+13.88 \%)$, rumenic acid (CHT $-1.88 \%$ and QUE $+24.24 \%$ ), stearic acid (CHT $+8.71 \%$ and QUE $-11.45 \%$ ), and saturated fatty acids (CHT $-0.47 \%$ and QUE - 3.38\%). These differences were probably due to the ability of condensed versus hydrolyzable tannins to interfere with rumen microbial metabolism, as indirectly confirmed by changes in the relative proportions of $B$. fibrisolvens and $B$. proteoclasticus populations and by changes in the molar proportions of volatile fatty acids. The effect of the

Received July 22, 2014.

Accepted October 17, 2014.

${ }^{1}$ Corresponding author: arianna.buccioni@unifi.it
CHT diet on the milk FA profile and microbial species considered in this trial was intermediate between that of QUE and the control diet, suggesting a differential effect of condensed and hydrolyzable tannins on rumen microbes. Compared with control animals, the presence of $B$. fibrisolvens increased about 3 times in ewes fed CHT and about 5 times in animals fed QUE. In contrast, the abundance of $B$. proteoclasticus decreased about 5- and 15-fold in rumen liquor of ewes fed CHT and QUE diets, respectively. The use of soybean oil and a practical dose of QUE or CHT extract in the diet of dairy ewes can be an efficient strategy to improve the nutritional quality of milk.

Key words: tannin, milk fatty acid, sheep, microbial population

\section{INTRODUCTION}

During the last decade, several efforts have been done to enhance the level of healthy FA in milk and dairy products with the aim of improving the nutritional quality of foods deriving from ruminants (Chilliard et al., 2007; Mele, 2009). This objective may be achieved by applying feeding strategies based on dietary supplementation with polyunsaturated marine or vegetables oils or oilseeds (Shingfield et al., 2013), to accumulate in the rumen conjugated linoleic acid (trans-11,cis-9 CLA) precursors such as trans-11 18:1 (vaccenic acid, VA), and to increase the duodenal passage of PUFA. Previous studies demonstrated that adding vegetable oils rich in linoleic acid (cis-9,cis-12 18:2; LA) oil in the diet of small ruminants increased the content of cis9,trans-11 CLA and VA in milk fat 2- to 3-fold (Mele et al., 2006, 2008; Gómez-Cortés et al., 2008). However, because the extent of rumen biohydrogenation $(\mathbf{B H})$ of PUFA is usually more than 80 to $90 \%$, the amount of supplemented lipid needed to achieve an effective enhancement of cis-9,trans-11 CLA and VA in milk fat from sheep and goats ranges from 60 to $100 \mathrm{~g} /$ head and 
day, leading to an increase in feeding costs. Moreover, although small ruminants are less sensitive than dairy cows to milk fat depression syndrome, high levels of lipids coupled with low forage diets may induce a decrease in milk fat content (Bauman and Griinari, 2003; Shingfield et al., 2013). As a consequence, in the last years, increasing interest has been devoted to feed ingredients able to slow the extent of rumen BH of dietary PUFA to obtain significant accumulations of VA in the rumen and, thus, an increase of the transfer of this FA from rumen to duodenum and then to the mammary gland (resulting in an increase of cis-9,trans-11 CLA, which originates by mammary desaturation of VA), while using lesser amounts of lipid supplementation.

Several in vitro studies have demonstrated that tannins are able to interfere with rumen $\mathrm{BH}$ or methane production, according to their polyphenolic nature (Bhatta et al., 2009; Khiaosa-Ard et al., 2009; Buccioni et al., 2011). Moreover, ewes and cows fed diets containing less than $4 \%$ tannins on a DM basis resulted in higher retention of nitrogen and lower plasma urea concentrations, because of the ability of tannin to protect feed protein from rumen microbial degradation (Frutos et al., 2004a). The effect on rumen microorganism activity has been related to the ability of tannins to interfere with the membranes of rumen bacteria, binding enzymes or by deprivation of metal ions, such as iron (Patra and Saxena, 2011). Among bacterial species involved in $\mathrm{BH}$ processes of PUFA, Butyrivibrio fibrisolvens and Butyrivibrio proteoclasticus seem to be the most sensitive (Vasta et al., 2010), but specific studies on the effects of different types of tannins on rumen microbial population are still scarce. Moreover, results from in vitro and in vivo experiments often show conflicting results on the effect of tannins on the accumulation of $\mathrm{BH}$ intermediates in the rumen and on the productive response of the animal (Vasta et al., 2009a; Toral et al., 2011, 2013). This is probably due to differences in tannin species and percentage inclusion in the diet and to associative effects between tannins and other diet ingredients such as lipids.

The aim of the present study was to evaluate the effect of moderate amount $(<2 \%)$ of chestnut or quebracho tannin extracts (hydrolyzable and condensed tannins, respectively) in diets supplemented with soybean oil on the milk FA profile and on the relative abundance of $B$. fibrisolvens and B. proteoclasticus in the rumen microbial community. Moreover, because sheep milk is mainly used for cheese making, a further objective of the present study was to evaluate the effect of tannin addition on the gross composition and clotting characteristics of milk. Finally, because tannins may exert a toxic effect in ruminants, causing necrosis of the liver and lesions in the digestive tract (Reed, 1995; Hervás et al., 2003a), this experiment studied the effect of these feeding strategies on blood parameters, with a special focus on indicators of hepatic function.

\section{MATERIALS AND METHODS}

\section{Experimental Design}

Animals. Eighteen multiparous Comisana ewes at $122 \pm 6$ DIM kept at the Experimental Section of the Department of Applied Biology, University of Perugia Italy, were allotted into 3 experimental groups, homogeneous for BW $(68.1 \pm 7.83 \mathrm{~kg})$, and each group was kept in multiple pens ( 6 ewes for each pen). The trial lasted $4 \mathrm{wk}$ after $15 \mathrm{~d}$ of adaptation to the feeding regimen. The handling of the animals was according to Institutional Animal Care and Use Committee of the University of Perugia. The ewes were milked twice daily at 0730 and $1730 \mathrm{~h}$ using a milking machine $(43 \mathrm{kPa}$; 150 pulsations/min), and daily individual milk yield was recorded.

Diets. The experimental diets were formulated according to the nutrient requirements of a ewe weighing $68 \mathrm{~kg}$ and producing $1 \mathrm{~kg}$ of milk at $6.5 \%$ fat (Cannas et al., 2004). Diets were composed of chopped grass hay (particle size $>4 \mathrm{~cm}$ in length) administered ad libitum and $800 \mathrm{~g} /$ head and day of a concentrate that contained $84.5 \mathrm{~g}$ of soybean oil $/ \mathrm{kg}$ of DM and $52.8 \mathrm{~g} / \mathrm{kg}$ of DM of bentonite (control diet, CON), or $52.8 \mathrm{~g} / \mathrm{kg}$ DM of chestnut tannins (CHT diet) or $52.8 \mathrm{~g} / \mathrm{kg} \mathrm{DM}$ of quebracho tannins (QUE diet). The chemical composition of feeds and the ingredients of concentrates are presented in Table 1. The dose of tannins was chosen to obtain a tannin concentration in the diet of almost $1.6 \%$ of expected DMI. On the basis of results from previous studies in literature, this dose was considered safe for the animal and practical for farmers (Hervás et al., 2003a,b; Frutos et al., 2004a,b). The experimental concentrates were offered after each milking, and 100 $\mathrm{g} /$ head of rolled barley was offered during milking. Chestnut hydrolyzable tannins $(750 \mathrm{~g} / \mathrm{kg}$ DM of tannic acid equivalent; by Gruppo Mauro Saviola srl Radicofani, Siena, Italy) and extract of quebracho tannins (456 g/kg DM of tannic acid equivalent; by Guido Lapi spa Castel Franco di Sotto, Pisa, Italy) were titrated according to Burns (1963).

\section{Sampling and Analysis}

Feed Sampling and Analysis. Samples of feeds and orts were weekly collected and stored at $-80^{\circ} \mathrm{C}$ until analysis. Samples were freeze-dried and then ground for chemical analysis using a Cyclotec 1093 mill (PBI International, Milan, Italy) using a mesh size of $1 \mathrm{~mm}$. 
Table 1. Ingredients, chemical composition, and FA profile of the experimental concentrates and the hay and rolled barley administered to ewes

\begin{tabular}{|c|c|c|c|c|c|}
\hline \multirow[b]{2}{*}{ Item } & \multirow{2}{*}{$\begin{array}{l}\text { Grass } \\
\text { hay }\end{array}$} & \multirow{2}{*}{$\begin{array}{l}\text { Rolled } \\
\text { barley }\end{array}$} & \multicolumn{3}{|c|}{ Experimental concentrate $^{1}$} \\
\hline & & & Control & $\mathrm{CHT}$ & QUE \\
\hline \multicolumn{6}{|l|}{ Ingredient, $\mathrm{g} / \mathrm{kg}$ of $\mathrm{DM}$} \\
\hline Barley & & & 213.8 & 213.8 & 213.8 \\
\hline Corn & & & 211.3 & 211.3 & 211.3 \\
\hline Wheat bran & & & 158.5 & 158.5 & 158.5 \\
\hline Soybean meal $(44 \% \mathrm{CP})$ & & & 126.8 & 126.8 & 126.8 \\
\hline Beet pulp & & & 89.8 & 89.8 & 89.8 \\
\hline Soybean oil $^{2}$ & & & 84.5 & 84.5 & 84.5 \\
\hline Bentonite & & & 52.8 & - & - \\
\hline Chestnut tannin extract ${ }^{3}$ & & & - & 52.8 & - \\
\hline Quebracho tannin extract ${ }^{4}$ & & & - & - & 52.8 \\
\hline Molasses & & & 41.3 & 41.3 & 41.3 \\
\hline $\mathrm{CaCO}_{3}$ & & & 10.6 & 10.6 & 10.6 \\
\hline Sodium bicarbonate & & & 5.3 & 5.3 & 5.3 \\
\hline Dicalcium phosphate & & & 5.3 & 5.3 & 5.3 \\
\hline \multicolumn{6}{|c|}{$\begin{array}{l}\text { Chemical composition, } \mathrm{g} / \mathrm{kg} \text { of } \mathrm{DM} \\
\text { (unless otherwise noted) }\end{array}$} \\
\hline OM & 847.0 & 859.9 & 816.9 & 858.1 & 869.6 \\
\hline $\mathrm{CP}$ & 111.2 & 121.0 & 165.6 & 173.7 & 170.3 \\
\hline Ether extract & 12.0 & 16.1 & 109.4 & 105.4 & 102.4 \\
\hline $\mathrm{NDF}$ & 636.4 & 134.1 & 174.7 & 181.4 & 172.1 \\
\hline $\mathrm{ADF}$ & 501.3 & 54.2 & 77.6 & 72.4 & 74.3 \\
\hline ADL & 105.7 & 14.9 & 10.6 & 13.3 & 8.7 \\
\hline Ash & 69.6 & 21.0 & 84.6 & 39.9 & 39.4 \\
\hline $\mathrm{ME}, \mathrm{MJ} / \mathrm{kg}$ of $\mathrm{DM}$ & 7.8 & 9.9 & 13.1 & 14.1 & 14.1 \\
\hline $\mathrm{NE}_{\mathrm{L}}, \mathrm{Mcal} / \mathrm{kg}$ of DM & 0.9 & 1.2 & 2.0 & 2.1 & 2.1 \\
\hline \multicolumn{6}{|l|}{$\mathrm{FA}, \mathrm{g} / 100 \mathrm{~g}$ of total $\mathrm{FA}$} \\
\hline $16: 0$ & 35.5 & 18.2 & 14.0 & 14.4 & 14.9 \\
\hline $18: 0$ & 5.8 & 4.6 & 3.6 & 3.4 & 3.4 \\
\hline $18: 1$ cis-9 & 9.3 & 21.2 & 23.3 & 22.9 & 22.0 \\
\hline $18: 2 n-6$ & 28.5 & 45.0 & 51.4 & 51.7 & 51.8 \\
\hline $18: 3 n-3$ & 2.8 & 6.0 & 5.8 & 5.6 & 5.8 \\
\hline Others & 18.1 & 4.9 & 1.9 & 2.0 & 2.1 \\
\hline
\end{tabular}

${ }^{1} \mathrm{CHT}=$ chestnut tannin extract; QUE $=$ quebracho tannin extract.

${ }^{2}$ Fatty acid profile of soybean oil (g/100 g of total FA) = 16:0, 11.01; 18:0, 3.6; cis-9 18:1, 22.09; cis-9, cis-12 18:2, 53.7; cis-9,cis-12,cis-15 18:3, 7.2.

${ }^{3}$ Hydrolyzable tannins extracted from chestnut wood (Castanea sativa) containing $750 \mathrm{~g}$ of tannic acid equivalent/kg of DM (provided by Gruppo Mauro Saviola srl Radicofani, Siena, Italy).

${ }^{4}$ Condensed tannins extracted from quebracho (Schinopsis lorentzii) containing $456 \mathrm{~g}$ of tannic acid equivalent/ kg of DM (provided by Guido Lapi spa, Castel Franco di Sotto, Pisa, Italy).

Crude protein, ether extract, and ash were determined according to the AOAC methods 976.06, 920.39, and 942.05, respectively (AOAC International, 1995). Neutral detergent fiber, ADF, and lignin were determined according to Van Soest et al. (1991) using heat-stable amylase and sodium sulfite, and results were expressed inclusive of residual ash. Metabolizable energy and $\mathrm{NE}_{\mathrm{L}}$ were calculated according to Cannas et al. (2004). Feed FA were extracted according to Folch et al. (1957), esterified according to Christie (1982) with 19:0 (Sigma Chemical Co., St Louis, MO) as the internal standard, and identified using the same procedure described below for FA of milk samples.

Milk Sampling and Analysis. Individual milk samples from morning and evening milking were collected weekly and allotted into 3 aliquots for analysis: the first aliquot was processed to assess fat, lactose, protein, and casein contents by using Milkoscan 6000 FT (Foss Electric, Hillerød Denmark), and total SCC according to ISO 13366-2/IDF 148-2 (ISO-IDF, 2006), by using a Fossomatic 5000 (Foss Electric) and expressed as linear score [linear score $=\log _{2}(\mathrm{SCC} / 12,500)$; Shook, 1993]. The second aliquot was processed to determine the milk rennet characteristics at $35^{\circ} \mathrm{C}$ by using a Maspress apparatus (Foss Italia, Padua, Italy), according to Zannoni and Annibaldi (1981). The following rennet parameters were determined: clotting time (r) - the time from rennet addition to the beginning of coagulation; firming time $\left(\mathbf{k}_{\mathbf{2 0}}\right)$ - the time needed for the amplitude to reach $20 \mathrm{~mm}$ on the recording chart; and curd firmness $\left(\mathbf{a}_{30}\right)$ - the amplitude of the trace 30 min after rennet addition. The third aliquot 
of milk samples was stored at $-80^{\circ} \mathrm{C}$ until analysis for FA extraction and composition by gas chromatography according to Buccioni et al. (2010). Individual FAME were quantified using valeric acid (5:0) and nonadecanoic acid (19:0) methyl esters (Sigma Chemical Co.) as internal standards and identified by comparison of the relative retention times of FAME peaks from samples, with those of the standard mixture 37 Component FAME Mix (Supelco, Bellefonte, PA; 4:0-24:0) and individual trans-9 18:1 and trans-11 18:1 (Sigma-Aldrich, St. Louis, MO), individual cis-9,trans-11 18:2 (Matreya Inc., Pleasant Gap, PA), CLA mix standard (SigmaAldrich, St. Louis, MO), and published isomeric profiles (Kramer et al., 1997, 2004; Cruz-Hernandez et al., 2006). The 18:1 isomer elution sequence was performed according to Kramer et al. (2008). Moreover, a standard mix of $\alpha$-linolenic acid ( $\boldsymbol{\alpha}$-LNA) isomers (47792, Supelco, Bellefonte, PA) and of LA isomers (47791, Supelco) and published isomeric profiles (Destaillats et al., 2005) were used to identify the isomers of interest. Two bacterial acid methyl ester mixes (Supelco; Matreya, Pleasant Gap, PA) and individual standard for methyl ester of iso 14:0, anteiso 14:0, iso 15:0, and anteiso 17:0 (Larodan, Malmo, Sweden) were used to identify the branched FA profile. Inter- and intraassay coefficients of variation were calculated by using a reference standard butter (CRM 164, Community Bureau of Reference, Brussels, Belgium), and the detection threshold of FA was $0.01 \mathrm{~g} / 100 \mathrm{~g}$ of FA (Contarini et al., 2013). All FA composition results are expressed in grams per 100 grams of FA.

Blood Sampling and Analysis. Samples of blood were collected from each animal at the end of every experimental week from the jugular vein. Blood was stored in tubes without anticoagulant, and serum was separated by centrifugation $(5,000 \times g$ for $30 \mathrm{~min}$ at $25^{\circ} \mathrm{C}$ ). Total protein (colorimetric biuret method ), urea (kinetic enzymatic method), albumin (ALB; colorimetric BCG method), $\gamma$-glutamyl-transferase $(\boldsymbol{\gamma}$-GT; kinetic SZASZ-Tris method), serum glutamic-oxaloacetic-transaminase (SGOT; kinetic UV IFCC method), and serum glutamic-pyruvic-transaminase (SGPT; kinetic UV IFCC method) were detected using diagnostic kits (ASR01120, ASR01143, ASR0128012, ASR01194, ASR01229, ASR01219, Assel s.r.l., Rome Italy) with an auto blood-analyzer for hematology (Vegavet AMS, Analyzer Medical System, Rome, Italy). Globulin (GBL) content was estimated by the difference between total protein and albumin contents.

Rumen Sampling and Analysis. On the last day of the experimental period, animals were milked and given free access to their ration for $1 \mathrm{~h}$, according to Toral et al. (2013). Then, feeds were removed and $3 \mathrm{~h}$ later, rumen liquor samples were collected from each ewe using a stomach tube connected to a manual pump. Immediately after collection, each sample of rumen liquor was measured for $\mathrm{pH}$, partitioned into 2 amounts and stored at $-80^{\circ} \mathrm{C}$ until analysis for total VFA content $(10 \mathrm{~mL})$ and microbiological assay (5 $\mathrm{mL})$. The analysis of VFA (2:0, acetic; 3:0, propionic; 4:0, butyric; iso 4:0, isobutyric; 5:0, valeric; iso 5:0, isovaleric) of rumen liquor samples was performed by HPLC: a volume of $10 \mathrm{~mL}$ of rumen liquor was diluted with $0.1 \mathrm{~N} \mathrm{H}_{2} \mathrm{SO}_{4}$ (1:1) and centrifuged $(5,000 \times g$ for $15 \mathrm{~min}$ at $4^{\circ} \mathrm{C}$ ) to separate the liquid phase from the feed residuals. After, the liquid phase was microfiltered (SLMV033RS, 0.45- $\mu \mathrm{m}$ Millex-HV, Merck-Millipore, Billerica, MA) and the sample was directly injected in the HPLC apparatus using an Aminex 85 HPX-87 H ion exclusion column $(300 \mathrm{~mm} \times 7.8 \mathrm{~mm}$; $9-\mu \mathrm{m}$ particle size; Bio-Rad, Milan, Italy) kept at $40^{\circ} \mathrm{C}$; the detection wavelength was $220 \mathrm{~nm}$. The analyses were carried out applying an isocratic elution (flux $0.6 \mathrm{~mL} / \mathrm{min}$ ) with a $0.008 \mathrm{~N} \mathrm{H}_{2} \mathrm{SO}_{4}$ solution as mobile phase; the injection loop was $20 \mu \mathrm{L}$. Individual VFA were identified using a standard solution of $4.50 \mathrm{mg} / \mathrm{mL}$ of acetic acid, 5.76 $\mathrm{mg} / \mathrm{mL}$ of propionic acid, $7.02 \mathrm{mg} / \mathrm{mL}$ of butyric acid and isobutyric acid, $8.28 \mathrm{mg} / \mathrm{mL}$ of valeric acid and isovaleric acid in $0.1 \mathrm{~N} \mathrm{H}_{2} \mathrm{SO}_{4}$ (338826, 402907, B103500, 58360, 75054, 129542, respectively; Sigma-Aldrich). Quantification was done using an external calibration curve based on the standards described above. Data were expressed in millimoles per liter.

DNA Extraction and Quantitative Real-Time PCR Analysis. Total DNA was extracted from $1 \mathrm{~mL}$ of rumen liquor using the Fast DNA SPIN kit for soil (Qbiogene, Carlsbad, CA) with some modifications. Briefly, each sample was thawed on ice, transferred to a 15 -mL tube containing $4.5 \mathrm{~mL}$ of a buffer solution (150 $\mathrm{m} M \mathrm{NaCl}, 10 \mathrm{~m} M$ Tris- $\mathrm{HCl}, \mathrm{pH}$ 8.0, $10 \mathrm{~m} M$ EDTA, and $4 \% \mathrm{SDS}$ ) and incubated for $15 \mathrm{~min}$ at $70^{\circ} \mathrm{C}$. The liquid was centrifuged at $200 \times g$ at $4^{\circ} \mathrm{C}$ for $5 \mathrm{~min}$. One milliliter of the supernatant was centrifuged at 14,600 $\times g$ at $4^{\circ} \mathrm{C}$ for $5 \mathrm{~min}$, and the pellet was processed according to the Fast DNA SPIN kit for soil. The extracted DNA was eluted in $50 \mu \mathrm{L}$ of nuclease-free water and its concentration and quality were verified by agarose gel electrophoresis. Relative abundances of B. fibrisolvens and B. proteoclasticus in rumen liquor samples were measured by real-time quantitative (q) PCR, using total bacterial DNA as reference (Denman and McSweeny, 2005). The primers used in this study were identified from the literature to amplify partial 16S rRNA gene of total bacteria (Maeda et al. 2003), B. fibrisolvens (Stevenson and Weimer 2007), and B. proteoclasticus (Paillard et al. 2007). For each primer pair, reaction efficiencies were derived from a standard curve generated from a 5-fold serial dilution of pooled 
DNA. Real-time qPCR analysis was performed using a CFX96 Real-Time PCR Detection System (Bio-Rad Laboratories, Hertfordshire, UK) in a total volume of $20 \mu \mathrm{L}$. For B. fibrisolvens and total bacteria, $0.5 \mathrm{ng}$ of DNA was added to $10 \mu \mathrm{L}$ of SSo Advanced Universal SYBR Green Supermix (Bio-Rad) and $400 \mathrm{n} M$ each primer. For B. proteoclasticus, $35 \mathrm{ng}$ of DNA was added to $10 \mu \mathrm{L}$ of SSo Advanced Universal Probes Supermix (Bio-Rad) containing $400 \mathrm{n} M$ of each primer and 250 $\mathrm{n} M$ of molecular beacon. Amplification conditions were $95^{\circ} \mathrm{C}$ for $3 \mathrm{~min}, 40$ cycles of $95^{\circ} \mathrm{C}$ for $15 \mathrm{~s}$, and $60^{\circ} \mathrm{C}(B$. fibrisolvens and total bacteria) or $55^{\circ} \mathrm{C}$ (B. proteoclasticus) for $30 \mathrm{~s}$. To determine amplification specificity, following all non-probe-based qPCR reactions, a melting curve was constructed in the range of $60^{\circ} \mathrm{C}$ to $95^{\circ} \mathrm{C}$. Cycle threshold values were converted into normalized relative quantities, corrected by PCR efficiency using Q-Gene software (Simon, 2003). The B. fibrisolvens and B. proteoclasticus $16 \mathrm{~S}$ rRNA gene values were expressed as percentage of total bacteria.

\section{Statistical Analysis of FA Data}

All data (e.g., animal performance, milk composition, and blood parameters) recorded over the course of the experiment were processed as a completely randomized design with repeated measures using the MIXED procedure of SAS (SAS Institute, 1999):

$$
\mathrm{y}_{\mathrm{ijkl}}=\mu+\mathrm{D}_{\mathrm{i}}+\mathrm{T}_{\mathrm{j}}+\mathrm{I}_{\mathrm{k}}(\mathrm{D})+(\mathrm{D} \times \mathrm{T})_{\mathrm{ij}}+\mathrm{e}_{\mathrm{ijkl}},
$$

where $y_{\mathrm{ijkl}}$ is the observation; $\mu$ is the overall mean; $D_{\mathrm{i}}$ is the fixed effect of $\operatorname{diet}\left(i=1\right.$ to 3 ); $T_{j}$ is the fixed effect of sampling time ( $\mathrm{j}=1$ to 4$) ; \mathrm{I}_{\mathrm{k}}$ is the random effect of the ewe nested within the diet $(\mathrm{k}=1$ to 6$) ;(\mathrm{D} \times$ $\mathrm{T})_{\mathrm{ij}}$ is the interaction between diet and sampling time; and $\mathrm{e}_{\mathrm{ijkl}}$ is the residual error. The covariance structure was compound symmetry, which was selected based on Akaike's information criterion of the mixed model of SAS. Statistical significance of the diet effect was tested against variance of sheep nested within diet according to repeated measures design theory (Littell et al., 1998).

Data of relative abundance of $B$. fibrisolvens and $B$. proteoclasticus were normalized by $\log _{10}$ transformation and checked for normal distribution by the ShapiroWilk test (SAS Institute, 1999). Data of VFA and normalized data of microbial abundance were processed using one-way ANOVA (SAS Institute, 1999) with a model that included diet and experimental error:

$$
\mathrm{y}_{\mathrm{ij}}=\mu+\mathrm{D}_{\mathrm{i}}+\mathrm{e}_{\mathrm{ij}},
$$

where $\mathrm{y}_{\mathrm{ij}}$ is the observation; $\mu$ is the overall mean; $\mathrm{D}_{\mathrm{i}}$ the diet ( $\mathrm{i}=1$ to 3 ); and $\mathrm{e}_{\mathrm{ij}}$ the residual error. Multiple comparisons among means were performed using the Tukey test.

\section{RESULTS}

\section{Animal Performance, Milk Composition, and Blood Parameters}

During the experiment, the concentrate offered was completely consumed by the animals, irrespective of treatment ( $\sim 760 \mathrm{~g} /$ head and day), allowing similar intakes of soybean oil ( $\sim 63 \mathrm{~g} /$ head and day) and tannin extracts for sheep in the CHT and QUE groups ( $\sim 40$ $\mathrm{g} /$ head and day). The average DMI of diet was $2.53 \pm$ $0.07,2.29 \pm 0.19$, and $2.25 \pm 0.11 \mathrm{~kg} /$ head and day for groups CON, CHT, and QUE, respectively.

Dietary treatments did not affect milk yield, whereas several milk components (except total solids and linear score) and rheological parameters (except clotting time) varied significantly $(P<0.01)$ over time, as shown in Table 2.

Blood parameters did not change across dietary treatments but they did change during the experimental period except for the glutamic transaminases SGPT and SGOT (Table 3 ). The diet $\times$ time interaction was significant for total protein and GLB (Table 3).

\section{Rumen $\mathrm{pH}$ and FA Profile}

The average $\mathrm{pH}$ value of rumen liquor was not affected by dietary treatments and was $6.69 \pm 0.07$. Compared with the control diet, the CHT and QUE diets influenced rumen fermentation, as indirectly confirmed by the changes in VFA profile (Table 4). In particular, QUE induced decreases in concentrations of acetic, propionic, valeric, and isovaleric acids $(P<0.05)$, whereas CHT enhanced concentrations of acetic $(P<0.05)$ and butyric acids $(P<0.01$; Table 4$)$.

\section{Effect of Tannins on Relative Abundance of $B$. fibrisolvens and $B$. proteoclasticus}

Supplementation with chestnut and quebracho tannins significantly affected the relative abundances of B. fibrisolvens and B. proteoclasticus in rumen liquor. The proportion of $B$. fibrisolvens ranged from 0.008 to $0.057 \%$ of total bacteria, whereas that of B. proteoclasticus ranged from 0.018 to $0.380 \%$. Compared with rumen liquor from ewes fed $\mathrm{CON}$, the presence of $B$. fibrisolvens increased about 3 -fold $(P<0.001)$ in ewes fed CHT and about 5 -fold $(P<0.001)$ in animals fed the QUE diet (Table 4). In contrast, the abundance of B. proteoclasticus decreased about 5 -fold $(P<0.001)$ and 15 -fold $(P<0.001)$ in rumen liquor of ewes fed CHT and QUE diets, respectively (Table 4). 
Table 2. Milk yield and composition(g/100 g, unless otherwise noted) from ewes fed $800 \mathrm{~g} / \mathrm{head}$ per day of a concentrate containing $84 \mathrm{~g}$ of soybean oil $/ \mathrm{kg}$ of DM plus 0 (control diet), $52.8 \mathrm{~g} / \mathrm{kg}$ of DM of a chestnut tannin extract (CHT diet), or $52.8 \mathrm{~g} / \mathrm{kg}$ of DM of quebracho tannin extract (QUE diet)

\begin{tabular}{|c|c|c|c|c|c|c|c|}
\hline Item & \multicolumn{3}{|c|}{ Diet } & SEM & \multicolumn{3}{|c|}{$P$-value ${ }^{1}$} \\
\hline $\begin{array}{l}\text { Milk yield, } \mathrm{g} / \mathrm{d} \\
\text { Milk composition }\end{array}$ & \multicolumn{6}{|c|}{ Milk composition } & 0.351 \\
\hline Fat & 7.20 & 7.15 & 7.26 & 0.510 & 0.340 & $<0.001$ & 0.981 \\
\hline Lactose & 4.78 & 4.69 & 4.81 & 0.100 & 0.400 & $<0.001$ & 0.981 \\
\hline Protein & 6.15 & 6.41 & 6.22 & 0.161 & 0.571 & $<0.001$ & 0.982 \\
\hline Casein index & 79.83 & 79.03 & 80.54 & 0.563 & 0.021 & $<0.001$ & 0.371 \\
\hline Linear score $^{3}$ & 4.20 & 3.43 & 3.77 & 1.354 & 0.760 & 0.591 & 0.141 \\
\hline \multicolumn{8}{|c|}{ Clotting parameters ${ }^{4}$} \\
\hline $\mathrm{r}, \min : \mathrm{s}$ & $20: 14$ & 21:07 & 19:38 & $3: 23$ & 0.372 & 0.751 & 0.791 \\
\hline $\mathrm{k}_{20}$, min:s & $1: 55$ & $1: 53$ & $1: 33$ & $0: 23$ & 0.141 & $<0.001$ & 0.231 \\
\hline $\mathrm{a}_{30}, \mathrm{~mm}$ & 39.37 & 36.57 & 42.01 & 10.63 & 0.430 & 0.003 & 0.991 \\
\hline
\end{tabular}

${ }^{1}$ Probability of significant effect due to experimental factors: $\operatorname{diet}(\mathrm{D})$, time $(\mathrm{T})$, and their interaction $(\mathrm{D} \times \mathrm{T})$.

${ }^{2}$ Casein index $=$ total casein/total protein $\times 100$.

${ }^{3}$ Linear score $=\log _{2}(\mathrm{SCC} / 12,500)$.

${ }^{4}$ Where $\mathrm{r}=$ clotting time - the time from rennet addition to the beginning of coagulation; $\mathrm{k}_{20}=$ firming time - the time needed for the amplitude to reach $20 \mathrm{~mm}$ on the recording chart; and $\mathrm{a}_{30}=$ curd firmness - the amplitude of the trace 30 min after rennet addition.

\section{FA Composition of Milk}

The FA profile of milk was modified by inclusion of tannin in the diets (Table 5). Milk PUFA content increased with CHT $(+0.97 \%)$ and QUE $(+15.24 \%)$ supplementation, but only the QUE diet resulted in an increase of MUFA content (QUE $+3.96 \%)$ and in a decrease in SFA content (QUE -3.38\%). Data are shown in Table 5. Tannins increased LNA, LA, and VA contents in milk fat $(P<0.001)$, and this effect was more evident with QUE supplementation, which also enhanced CLA content. Compared with both CON and CHT diets, the QUE diet resulted in a significant decrease $(P<0.01)$ of 18:0. On the other hand, the content of 18:0 was highest in milk from ewes fed CHT diet. Interestingly, the desaturation index was higher in milk fat from ewes fed QUE diet than in milk fat from the other 2 groups $(P<0.01)$. Feeding the QUE diets increased both cis-9 18:1 (oleic acid) and cis-12 18:1 contents, whereas cis-11 18:1 decreased $(P<0.01)$. The content of trans-12 18:1, in contrast, increased with CHT $(P<0.01)$. No differences were found among diets for trans-10 18:1 and trans-10,cis-12 18:2, the latter being present only in trace amounts (data not shown). Both diets including tannins, moreover, decreased concentrations of 14:0 $(P<0.01)$, iso 14:0 $(P<0.05)$, 16:0 $(P<0.01)$, and iso 16:0 $(P<0.05)$ and increased concentrations of cis-9 16:1 $(P<0.01)$ and cis-9 17:1 $(P<$ 0.05); only the CHT diet decreased anteiso 17:0 $(P<$ 0.01 ). The amount of branched-chain FA significantly

Table 3. Blood parameters from ewes fed $800 \mathrm{~g} /$ head per day of a concentrate containing $84 \mathrm{~g}$ of soybean oil $/ \mathrm{kg}$ of DM plus 0 (control diet), $52.8 \mathrm{~g} / \mathrm{kg}$ of DM of a chestnut tannin extract (CHT diet), or $52.8 \mathrm{~g} / \mathrm{kg}$ of DM of quebracho tannin extract (QUE diet)

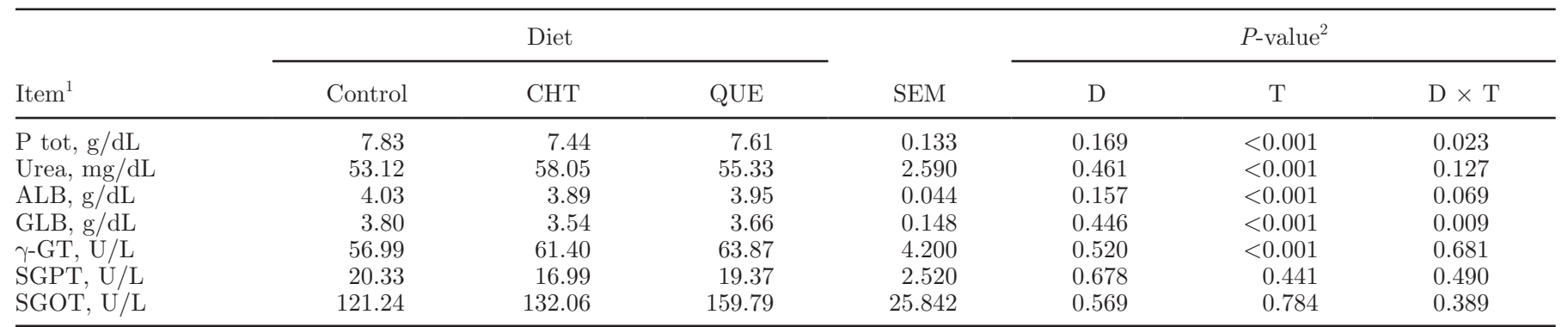

${ }^{1} \mathrm{P}$ tot $=$ total protein; $\mathrm{ALB}=$ albumin; GBL $=$ globulin; $\gamma$-GT $=\gamma$-glutamyltransferase; SGPT $=$ serum glutamic-pyruvic-transaminase; SGOT $=$ serum glutamic-oxaloacetic-transaminase.

${ }^{2}$ Probability of significant effect due to experimental factors: diet (D), time (T), and their interaction $(\mathrm{D} \times \mathrm{T})$. 
Table 4. Effect of tannins on VFA composition and relatives abundances of Butyrivibrio species in rumen liquor at the end of the experimental period from ewes fed $800 \mathrm{~g} /$ head per day of a concentrate containing $84 \mathrm{~g}$ of soybean oil $/ \mathrm{kg}$ of DM plus 0 (control diet), $52.8 \mathrm{~g} / \mathrm{kg}$ of DM of a chestnut tannin extract (CHT diet), or $52.8 \mathrm{~g} / \mathrm{kg}$ of DM of quebracho tannin extract (QUE diet)

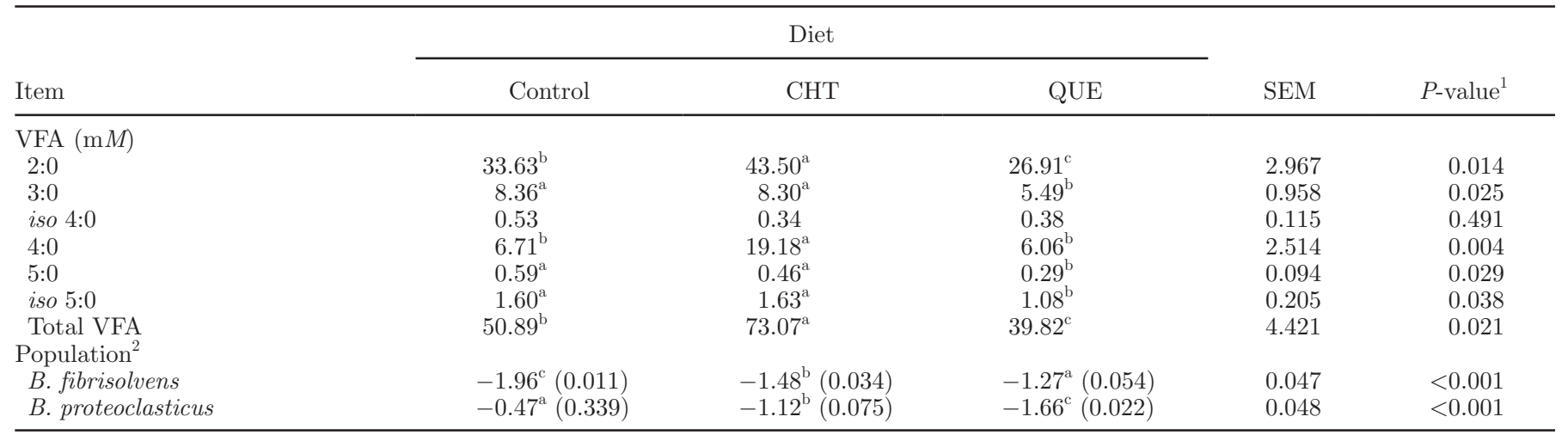

\footnotetext{
${ }^{\mathrm{a}-\mathrm{c}}$ Means within a row with different letters differ $(P<0.05)$.

${ }^{1}$ Probability of significant effect due to experimental factors: diet; means within a row with different letters differ $(P<0.05)$.

${ }^{2} \log _{10}$ of $\% 16 \mathrm{~S}$ rRNA gene of total bacteria (observed values in parentheses).
}

decreased in milk fat from ewes fed either the QUE or CHT diet, particularly that of iso 14:0, iso 15:0, anteiso 15:0, iso 16:0, and anteiso 17:0 (Table 5).

\section{DISCUSSION}

In the present trial, the intake of almost $40 \mathrm{~g} / \mathrm{head}$ and day of chestnut or quebracho tannin extract had no detrimental effects on blood parameters or productive performance. However, based on the diet $\times$ time interaction on total protein and GLB, further studies are needed to assess if long-term supplementation of dietary tannins may significantly affect protein utilization by dairy sheep. These data are in accordance with Liu et al. (2011) and Toral et al. (2011, 2013), who evaluated the effects of chestnut and quebracho tannins on growth and productive performances in ewes. The literature reports that condensed tannins are not absorbed in the intestine and, hence, they are not able to interfere with the metabolism of organs such as liver (McSweeney et al., 1988; Garg et al., 1992; Terrill et al., 1994). On the other hand, several researchers have demonstrated that rumen microorganisms are able to degrade hydrolyzable tannins, the toxicity of which seems to be due to absorption and accumulation of phenols in the bloodstream because of the liver's inability to completely detoxify them (Murdiati, 1992; Makkar, 2003). In this trial, the blood parameters of ewes showed that hepatic functionality was not perturbed by QUE and by CHT extract. Recently, Liu et al. (2013), in a feeding trial using dairy cows during the transition period, demonstrated that chestnut tannins were able to reduce the oxidative status of liver and to decrease the inflammatory status of mammary gland. Although the literature reports that ellagic acid and ellagitannins contained in fruits, nuts, seeds, and woods (e.g., chestnut tree) are metabolized in the stomach and small intestine, forming urolithins that are potent antiinflammatory agents targeting several tissues, including mammary gland (Cerdá et al., 2005; Espín et al., 2007; Landete, 2011), no effects were observed on milk SCC in the present study. However, SCC is only an indirect marker of the inflammatory status of the mammary gland.

In the current study, both CHT and QUE diets showed a significant effect on rumen microbial metabolism, as confirmed by the variation in several branched-chain FA in milk, that are an important diagnostic parameter for rumen microbial activity (Vlaeminck et al., 2006; Fievez et al., 2012). Interestingly, the ratio between iso and anteiso odd branched-chain FA, which is related to growth of cellulolytic bacteria (Vlaeminck et al., 2006), showed a similar trend to that observed for the acetic acid and total VFA concentrations, that increased with CHT and decreased with QUE (Table 4 and 5). Several differences were observed, in the molar proportion of rumen VFA among treatments, because the CHT diet increased the concentrations of acetic and butyric acids, whereas the QUE diet decreased all VFA with the exception of butyric acid. Interestingly, according to Waghorn (2008), hydrolyzable tannins contained in chestnut may be metabolized in the rumen to gallic and ellagic acids, which may be further metabolized to acetic and butyric acids. In the case of tannins from the QUE diet, the strong effect on VFA concentration was probably due to the depressive effect of condensed tannins on both carbohydrate and protein degradation, leading, in the last case, to reductions of VFA such as valeric and isovaleric acids, which origin from deamination of amino acids (Patra and Saxena, 2011). However, 
Table 5. Fatty acid composition of milk from sheep fed $800 \mathrm{~g} /$ head per day of a concentrate containing $84 \mathrm{~g}$ of soybean oil/kg of DM plus 0 (control diet), $52.8 \mathrm{~g} / \mathrm{kg}$ of DM of a chestnut tannin extract (CHT diet), or $52.8 \mathrm{~g} / \mathrm{kg}$ of DM of quebracho tannin extract (QUE diet)

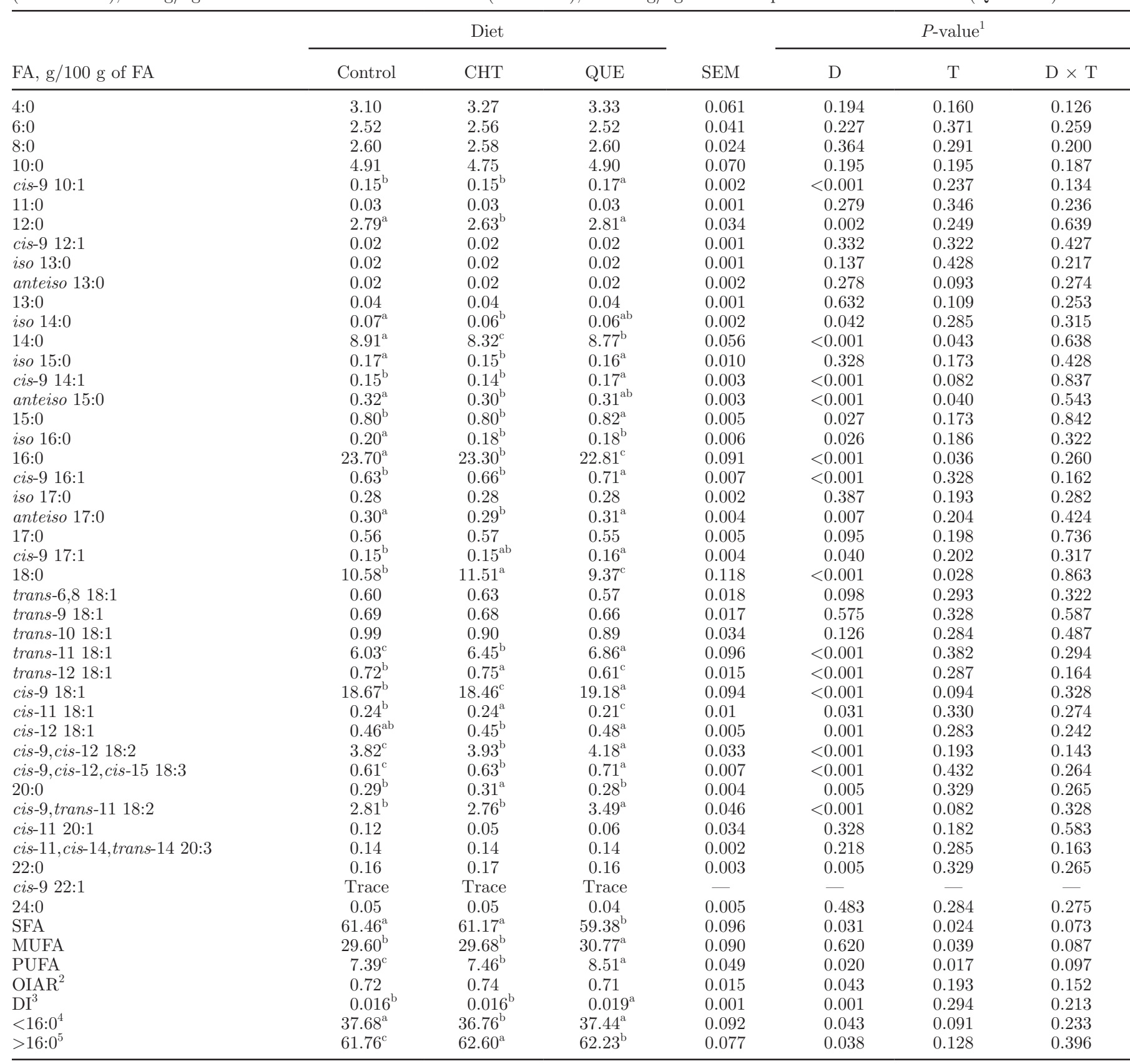

${ }^{\mathrm{a}-\mathrm{c}}$ Means within a row with different letters differ $(P<0.05)$.

${ }^{1}$ Probability of significant effect due to experimental factors: diet $(\mathrm{D})$, time $(\mathrm{T})$, and their interaction $(\mathrm{D} \times \mathrm{T})$.

${ }^{2}$ Ratio of odd-iso to odd-anteiso FA: (iso 15:0 + iso 17:0)/(anteiso 15:0 + anteiso 17:0).

${ }^{3}$ Desaturation index (cis-9 14:1/14:0 + cis-9 14:1).

${ }^{4}$ De novo fatty acids calculated according to Fievez et al. (2012).

${ }^{5}$ Preformed FA calculated according to Chilliard et al. (2000) and Fievez et al. (2012).

previous studies reported controversial data concerning the effect of tannins on total VFA or on their molar proportion in rumen liquor. Hervás et al. (2003b), Liu et al. (2011), and Toral et al. (2011), in fact, found that tannins did not affect total VFA concentration or their molar proportions in rumen liquor from ewes, whereas Bhatta et al. (2009) found that condensed tannins from mimosa reduced total VFA and increased production of 
propionate. These controversial results may arise from the use of different dosages or different kind of tannins and of associative effects between tannins and other ingredients of the basal diet.

Data about the microbiologic characterization of $\mathrm{ru}-$ men liquor showed that the presence of tannins resulted in an increase in relative abundance of $B$. fibrisolvens, whereas the $B$. proteoclasticus population was strongly depressed, particularly with the QUE diet. These data are in accordance with previous in vivo and in vitro studies (Vasta et al., 2010; Buccioni et al., 2011) that reported a significant effect of CHT and QUE on rumen $\mathrm{BH}$, favoring the accumulation of VA and negatively affecting the growth of B. proteoclasticus. Hence, the effect of tannin extracts on the milk FA profile observed in the present experiment could be due to the modulation of rumen $\mathrm{BH}$ because of changes in the microbial ecosystem. Nevertheless, some in vivo studies on rumen bacterial diversity in cows and ewes suggest that $B$. fibrisolvens and $B$. proteoclasticus do not play a dominant role in rumen lipid metabolism and that other as-yet-uncultured bacteria phylogenetically classified as Prevotella, Lachnospinaceae incertae sedis, and unclassified Bacteroidales, Clostridiales, and Ruminococcaceae might be more relevant (Boeckaert et al., 2008; Belenguer et al., 2010; Huws et al., 2011; Castro-Carrera et al., 2014). The literature also provides evidence that alterations in rumen outflow of 18-carbon $\mathrm{BH}$ intermediates and 18:0 induced by diets based on different types of forages or supplemented with fish oil are not accompanied by significant changes in B. proteoclasticus group (Kim et al., 2008; Huws et al., 2010; Halmemies-Beauchet-Filleau et al., 2013). Because diet composition plays a fundamental role in the selection of rumen microorganisms, further studies are needed to better clarify the effect of tannins on specific bacterial strains involved in $\mathrm{BH}$ processes. Moreover, data in the present experiment suggested that the CHT and QUE extracts affected milk FA composition in different ways, not only by modulating $\mathrm{BH}$ of LA. The SA content in milk fat, in fact, was significantly lower in samples from ewes fed the QUE diet, whereas the CHT diet resulted in the highest content of SA. At the same time, compared with that in CON, OA content was higher in milk fat from ewes fed QUE diet and lower in the milk fat from ewes fed the CHT diet. The content of SA (as well as that of OA, VA, and cis-9,trans-11 CLA) in milk fat is strictly regulated by the uptake of mammary tissue and by stearoyl Co-A desaturase enzyme (SCD) activity, which converts SA to OA and VA to cis-9,trans-11 CLA. In particular, almost $50 \%$ of OA and cis-9,trans-11 CLA secreted in sheep milk originates from SCD activity (Frutos et al., 2014). In regard to this last point, it is worth noting that the ratio of $14: 1$ to $14: 0$, which is considered a proxy of $\Delta^{9}$ desaturation in the mammary gland (Mele et al., 2007), was significantly higher in milk fat from ewes fed the QUE diet, suggesting a positive effect of this type of tannin extract on the activity of SCD, which in turn affected the ratio between substrate and products of the enzyme. Similar results were reported by Vasta et al. (2009b) in intramuscular fat of lambs fed green herbage with QUE tannin. However, whether condensed tannins affect directly or indirectly (for instance, by modulating the substrate availability to the mammary gland) the activity of SCD enzyme needs further investigation.

Saturated FA content was significantly decreased by both tannin treatments, but the effect was more evident for the QUE diet, probably due to the depressive effect of PUFA on milk fat synthesis in mammary gland (Shingfield et al., 2013). The PUFA content, in fact, was significantly higher in milk fat from ewes fed the QUE diet, whereas that from ewes fed the CHT diet was intermediate (Table 5). As regards FA involved in the rumen $\mathrm{BH}$, the QUE diet significantly enhanced the content of LA in milk fat, which accounted for more than $4 \%$ of total milk FA and enhanced the content of intermediates of its BH (cis-9,trans-11 CLA and VA), which accounted for more than 3 and $6 \%$ of milk FA, respectively. In addition, cis-12 18:2, a putative intermediate of rumen $\mathrm{BH}$, was significantly but marginally enhanced by the QUE diet (Table 5). Previous experiments based on the use of similar or higher amounts of soybean oil in the diet of dairy ewes (Mele et al., 2006; Gómez-Cortés et al., 2008) reported lower levels of VA and cis-9,trans-11 CLA in milk fat (similar to that found for the control diet in the present study), suggesting a significant effect of QUE tannins in the last step of rumen $\mathrm{BH}$ of LA (managed by B. proteoclasticus), which probably resulted in an increased flux of VA (and maybe of cis-9,trans-11 CLA) to the mammary gland. Because cis-9,trans-11 CLA is mainly produced in the mammary gland by $\Delta^{9}$-desaturation of VA (Bauman and Griinari, 2003), the content of cis9,trans-11 CLA also significantly increased. In the case of the CHT diet, the amount of LA and its rumen $\mathrm{BH}$ products in milk fat were intermediate between control and QUE treatments, suggesting a differential effect of hydrolyzable tannins compared with condensed tannins, as also shown by the relative quantification of $B$. fibrisolvens and B. proteoclasticus populations in rumen fluid (Table 4). These results did not agree with findings reported by Toral et al. (2011, 2013), who evaluated the effect of both quebracho and chestnut tannins on milk FA composition in dairy ewes fed a diet rich in LA. In both studies, those authors reported that tannins were not able to affect BH of LA, as suggested by the lack of significant changes in milk FA composition. 
In those experiments, however, the amount of quebracho $(58.98 \mathrm{~g} / \mathrm{head}$ and day) or chestnut tannins (26.21 $\mathrm{g} /$ head and day) were, respectively, higher and lower than that adopted in the present trial $(\sim 40 \mathrm{~g} /$ head and day), and the diets consisted of a TMR instead of ad libitum administration of hay (such as adopted in this experiment), suggesting that the effect of tannins on rumen $\mathrm{BH}$ could depend on the dose included in the diet, the diet composition, and the physical form of the basal diet. The content of trans-10 18:1 in milk fat did not differ across treatments, and the content of trans-10,cis-12 18:2 was below the limit of detection. Previous in vitro and in vivo studies reported that tannins did not stimulate alternative rumen $\mathrm{BH}$ pathway of LA and, therefore, no accumulation of trans-10 18:1 and 18:2 isomers has been reported (Vasta et al., 2009a; Buccioni et al., 2011; Toral et al., 2011; Vasta and Luciano, 2011). However, Toral et al. (2013) reported that QUE tannins tended to increase trans-10 18:1 content in milk fat over time, suggesting that the effects of tannins should be evaluated in long-term experiments.

\section{CONCLUSIONS}

The use of soybean oil in the diet of dairy ewes coupled with practical doses of quebracho or chestnut tannin extracts resulted in significant changes of milk FA composition without affecting other milk components, milk yield, or hepatic functionality. In particular, the QUE diet seemed to be more efficient in disturbing rumen BH of PUFA, increasing contents of cis-9,trans-11 CLA and VA in milk fat. The perturbing effect of tannin extracts on rumen $\mathrm{BH}$, and on microbe metabolism generally, was indirectly confirmed by the relative abundance of $B$. fibrisolvens and B. proteoclasticus populations and by the VFA molar proportion results. However, dose-response studies are needed to elucidate the minimum amount of tannin extracts needed to obtain a reliable and reproducible effect of $\mathrm{LA}$ on $\mathrm{BH}$ to maximize the enrichment of VA and cis-9,trans-11 CLA contents in milk fat using lower amounts of lipid supplementation. Finally, although neither type of tannin extract affected hepatic functionality or mammary gland health, studies involving long-term supplementation of hydrolyzable and condensed tannins are needed to confirm this result over a longer period.

\section{ACKNOWLEDGMENTS}

The authors thank Roberta Pastorelli (Centro di Ricerca per l'Agrobiologia e la Pedologia, Consiglio per la Ricerca e la sperimentazione in Agricoltura, Firenze, Italy), Antonio Pezzati and Doria Benvenuti (Dipartimento di Scienze delle Produzioni Agro-alimentari e
dell'Ambiente, Firenze, Italy) for their valuable technical assistance in the laboratory, and Giuseppe Ponti, Attilio Mazzocanti, and Giuseppe Covarelli (Dipartimento di Scienze Agrarie, Alimentari ed Ambientali, Perugia, Italy) for their technical assistance in animal management during the trial. This research was financed by the Universities of Florence, Pisa, and Perugia, and by Gruppo Mauro Saviola srl.

\section{REFERENCES}

AOAC International. 1995. Official Methods of Analysis. AOAC International, Gaithersburg, MD.

Bauman, D. E., and J. M. Griinari. 2003. Nutritional regulation of milk fat synthesis. Annu. Rev. Nutr. 23:203-227.

Belenguer, A., P. G. Toral, P. Frutos, and G. Hervás. 2010. Changes in the rumen bacterial community in response to sunflower oil and fish oil supplements in the diet of dairy sheep. J. Dairy Sci. 93:3275-3286

Bhatta, R., Y. Uyeno, K. Tajima, A. Takenaka, Y. Yabumoto, I. Nonaka, O. Enishi, and M. Kurihara. 2009. Difference in the nature of tannins on in vitro ruminal methane and volatile fatty acid production and on methanogenic archaea and protozoal populations. J. Dairy Sci. 92:5512-5522.

Boeckaert, C., B. Vlaeminck, V. Fievez, L. Maignien, J. Dijkstra, and N. Boon. 2008. Accumulation of trans C18:1 fatty acids in the rumen after dietary algal supplementation is associated with changes in the Butyrivibrio community. Appl. Environ. Microbiol. 74:6923-6930.

Buccioni, A., S. Minieri, S. Rapaccini, M. Antongiovanni, and M. Mele. 2011. Effect of chestnut and quebracho tannins on fatty acid profile in rumen liquid- and solid-associated bacteria: an in vitro study. Animal 5:1521-1530.

Buccioni, A., S. Rapaccini, M. Antongiovanni, S. Minieri, G. Conte, and M. Mele. 2010. Conjugated linoleic acid (CLA) and C18:1 isomers content in milk fat of sheep and their transfer to Pecorino Toscano D.O.P. cheese. Int. Dairy J. 20:190-194.

Burns, R. E. 1963. Methods of tannin analysis for forage crop evaluation. Technical Bulletin number 32. Georgia Agricultural Experiment Station, Athens.

Cannas, A., L. O. Tedeschi, D. G. Fox, A. N. Pell, and P. J. Van Soest. 2004. A mechanistic model for predicting the nutrients requirements and feed biological values for sheep. J. Anim. Sci. 82:149-169.

Castro-Carrera, T., P. G. Toral, P. Frutos, N. R. McEwan, G. Hervás, L. Abecia, E. Pinloche, S. E. Girdwood, and A. Belenguer. 2014. Rumen bacterial community evaluated by 454 pyrosequencing and terminal restriction fragment length polymorphism analyses in dairy sheep fed marine algae. J. Dairy Sci. 97:1661-1669.

Cerdá, B., F. A. Tomas-Barberan, and J. C. Espin. 2005. Metabolism of antioxidant and chemopreventive ellagitannins from strawberries, raspberries, walnuts, and oak-aged wine in humans: Identification of biomarkers and individual variability. J. Agric. Food Chem. 53:227-235.

Chilliard, Y., A. Ferlay, R. M. Mansbridge, and M. Doreau. 2000. Ruminant milk fat plasticity: Nutritional control of saturated, polyunsaturated, trans and conjugated fatty acids. Ann. Zootech. 49:181-205.

Chilliard, Y., F. Glasser, A. Ferlay, L. Bernard, J. Rouel, and M. Doreau. 2007. Diet, rumen biohydrogenation and nutritional quality of cow and goat milk fat. Eur. J. Lipid Sci. Technol. 109:828855.

Christie, W. W. 1982. A simple procedure for rapid trans-methylation of glycerolipids and cholesterol esters. J. Lipid Res. 23:1072-1075.

Contarini, G., M. Povolo, V. Pelizzola, L. Monti, and G. Lercker. 2013. Interlaboratory evaluation of milk fatty acid composition by using different GC operating conditions. J. Food Compos. Anal. $32: 131-140$. 
Cruz-Hernandez, C., J. K. G. Kramer, J. Kraft, V. Santercole, M. Or-Rashid, Z. Deng, M. E. R. Dugan, P. Delmonte, and M. P. Yurawecz. 2006. Systematic analysis of trans and conjugated linoleic acids in the milk and meat of ruminants. Pages 45-93 in Advances in Conjugated Linoleic Acid Research. Vol. 3. M. P. Yurawecz, J. K. G. Kramer, O. Gudmundsen, M. W. Pariza, and S. Banni, ed. AOCS Press, Champaign, IL.

Denman, S. E., and C. S. McSweeny. 2005. Quantitative (real-time) PCR. Pages 105-118 in Methods in Gut Microbial Ecology for Ruminants. H. P. S. Makkar, and C. S. McSweeney ed. Springer, Dordrecht, the Netherlands.

Destaillats, F., J. P. Trottier, J. M. G. Galvez, and P. Angers. 2005. Analysis of alpha-linolenic acid biohydrogenation intermediates in milk fat with emphasis on conjugated linolenic acids. J. Dairy Sci. 88:3231-3239.

Espín, J. C., R. Gonzalez-Barrio, B. Cerda, C. Lopez-Bote, A. I. Rey, and F. A. Tomas-Barberan. 2007. Iberian pig as model to clarify obscure points in the bioavailability and metabolism of ellagitannins in humans. J. Agric. Food Chem. 55:10476-10485.

Fievez, V., E. Colman, J. M. Castro-Montoya, I. Stefanov, and B. Vlaeminck. 2012. Milk odd- and branched-chain fatty acids as biomarkers of rumen function-An update. Anim. Feed Sci. Technol. 172:51-65.

Folch, J., M. Lees, and G. H. Sloane Stanley. 1957. A simple method for the isolation and purification of total lipids from animal tissue. J. Biol. Chem. 226:497-509.

Frutos, P., G. Hervás, F. J. Giráldez, and A. R. Mantecón. 2004a. Review: Tannins and ruminant nutrition. Span. J. Agric. Res. 2:191-202.

Frutos, P., M. Raso, G. Hervás, A. R. Mantecón, V. Pérez, and F. J. Giráldez. 2004b. Is there any detrimental effect when a chestnut hydrolysable tannin extract is included in the diet of finishing lambs? Anim. Res. 53:127-136.

Frutos, P., P. G. Toral, E. Ramos-Morales, K. J. Shingfield, A. Belenguer, and G. Hervás. 2014. Oral administration of cobalt acetate alters milk fatty acid composition, consistent with an inhibition of stearoyl-coenzyme A desaturase in lactating ewes. J. Dairy Sci. 97:1036-1046.

Garg, S. K., H. P. S. Makkar, K. B. Nagal, S. K. Sharma, D. R Wadhwa, and B. Singh. 1992. Toxicological investigations into oak (Quercus incana) leaf poisoning in cattle. Vet. Hum. Toxicol. 34:161-164.

Gómez-Cortés, P., P. Frutos, A. R. Mantecón, M. Juárez, M. A. De La Fuente, and G. Hervás. 2008. Milk production, conjugated linoleic acid content, and in vitro ruminal fermentation in response to high levels of soybean oil in dairy ewe diet. J. Dairy Sci. 91:1560-1569.

Halmemies-Beauchet-Filleau, A., P. Kairenius, S. Ahvenjärvi, L. K. Crosley, S. Muetzel, P. Huhtanen, A. Vanhatalo, V. Toivonen, R. J. Wallace, and K. J. Shingfield. 2013. Effect of forage conservation method on ruminal lipid metabolism and microbial ecology in lactating cows fed diets containing a 60:40 forage-to-concentrate ratio. J. Dairy Sci. 96:2428-2447.

Hervás, G., P. Frutos, F. J. Giráldez, A. R. Mantecón, and M. C. Álvarez Del Pino. 2003b. Effect of different doses of quebracho tannins extract on rumen fermentation in ewes. Anim. Feed Sci. Technol. 109:65-78.

Hervás, G., V. Pérez, F. J. Giráldez, A. R. Mantecón, M. M. Almar, and P. Frutos. 2003a. Intoxication of sheep with quebracho tannin extract. J. Comp. Pathol. 129:44-54.

Huws, S. A., E. J. Kim, M. R. F. Lee, M. B. Scott, J. K. S. Tweed, E. Pinloche, R. J. Wallace, and N. D. Scollan. 2011. As yet uncultured bacteria phylogenetically classified as Prevotella, Lachnospiraceae incertae sedis and unclassified Bacteroidales, Clostridiales and Ruminococcaceae may play a predominant role in ruminal biohydrogenation. Environ. Microbiol. 13:1500-1512.

Huws, S. A., M. R. F. Lee, S. M. Muetzel, M. B. Scott, R. J. Wallace, and N. D. Scollan. 2010. Forage type and fish oil cause shifts in rumen bacterial diversity. FEMS Microbiol. Ecol. 73:396-407.

ISO-IDF. 2006. ISO13366-2/IDF148-2: Milk-Enumeration of somatic cells-Part 2: Guidance on the operation of fluoro-opto-electronic counters. International Organization for Standardization (ISO),
Geneva, Switzerland; International Dairy Federation (IDF), Brussels, Belgium.

Khiaosa-Ard, R., S. F. Bryner, M. R. L. Scheeder, H. R. Wettstein, F. Leiber, and M. Kreuzer. 2009. Evidence for the inhibition of the terminal step of ruminal $\alpha$-linolenic acid biohydrogenation by condensed tannins. J. Dairy Sci. 92:177-188.

Kim, E. J., S. A. Huws, M. R. F. Lee, J. D. Wood, S. M. Muetzel, R. J. Wallace, and N. D. Scollan. 2008. Fish oil increases the duodenal flow of long chain polyunsaturated fatty acids and trans-11 18:1 and decreases 18:0 in steers via changes in the rumen bacterial community. J. Nutr. 138:889-896.

Kramer, J. K. G., C. Cruz-Hernandez, Z. Y. Deng, J. Q. Zhou, G. Jahreis, and M. E. R. Dugan. 2004. Analysis of conjugated linoleic acid and trans 18:1 isomers in synthetic and animal products. Am. J. Clin. Nutr. 79:1137S-1145S

Kramer, J. K. G., V. Fellner, M. E. R. Dugan, F. D. Sauer, M. M. Mossoba, and M. P. Yurawecz. 1997. Evaluating acid and base catalysts in the methylation of milk and rumen fatty acids with special emphasis on conjugated dienes and total trans fatty acids. Lipids 32:1219-1228.

Kramer, J. K. G., M. Hernandez, C. Cruz-Hernandez, J. Kraft, and M. E. R. Dugan. 2008. Combining results of two GC separations partly achieves determination of all cis and trans 16:1, 18:1, 18:2 and 18:3 except CLA isomers of milk fat as demonstrated using Ag-ion SPE fractionation. Lipids 43:259-273.

Landete, J. M. 2011. Ellagitannins, ellagic acid and their derived metabolites: A review about source, metabolism, functions and health. Food Res. Int. 44:1150-1160.

Littell, R. C., P. R. Henry, and C. B. Ammerman. 1998. Statistical analysis of repeated measures data using SAS procedures. J. Anim. Sci. 76:1216-1231.

Liu, H., V. Vaddella, and D. Zhou. 2011. Effect of chestnut tannins and coconut oil on growth performance, methane emission, ruminal fermentation, and microbial populations in sheep. J. Dairy Sci. 94:6069-6077.

Liu, H. W., D. W. Zhou, and K. Li. 2013. Effects of chestnut tannins on performance and antioxidative status of transition dairy cows. J. Dairy Sci. 96:5901-5907.

Maeda, H., C. Fujimoto, Y. Haruki, T. Maeda, S. Kokeguchi, M. Petelin, H. Arai, I. Tanimoto, F. Nishimura, and S. Takashiba. 2003 Quantitative real-time PCR using TaqMan and SYBR Green for Actinobacillus actinomycetemcomitans, Porphyromonas gingivalis, Prevotella intermedia, tetQ gene and total bacteria. FEMS Immunol. Med. Microbiol. 39:81-86.

Makkar, H. P. S. 2003. Effects and fate of tannins in ruminant animals, adaptation to tannins, and strategies to overcome detrimental effects of feeding tannin-rich feeds. Small Rumin. Res. 49:241-256.

McSweeney, C. S., P. M. Kennedy, and A. John. 1988. Effect of ingestion of hydrolysable tannins in Terminalia oblongata on digestion in sheep fed Stylosanthes hamata. Aust. J. Agric. Res. 39:235-244.

Mele, M. 2009. Designing milk fat to improve healthfulness and functional properties of dairy products: From feeding strategies to a genetic approach. Ital. J. Anim. Sci. 8:365-373.

Mele, M., A. Buccioni, F. Petacchi, A. Serra, S. Banni, M. Antongiovanni, and P. Secchiari. 2006. Effect of forage/concentrate ratio and soybean oil supplementation on milk yield and composition from Sarda ewes. Anim. Res. 55:273-285.

Mele, M., G. Conte, B. Castiglioni, S. Chessa, N. P. P. Macciotta, A. Serra, A. Buccioni, G. Pagnacco, and P. Secchiari. 2007. Stearoylcoenzyme A desaturase gene polymorphism and milk fatty acid composition in Italian Holsteins. J. Dairy Sci. 90:4458-4465.

Mele, M., A. Serra, A. Buccioni, G. Conte, A. Pollicardo, and P. Secchiari. 2008. Effect of soybean oil supplementation on milk fatty acid composition from Saanen goats fed diets with different forage:concentrate ratios. Ital. J. Anim. Sci. 7:297-311.

Murdiati, T. B. 1992. Metabolism in sheep of garlic acid, tannic acid and hydrolysable tannin from Terminalia oblongata. Aust. J. Agric. Res. 43:1307-1319.

Paillard, D., N. McKain, M. T. Rincon, K. J. Shingfield, D. I. Givens, and R. J. Wallace. 2007. Quantification of ruminal Clostridium 
proteoclasticum by real-time PCR using a molecular beacon approach. J. Appl. Microbiol. 103:1251-1261.

Patra, A. K., and J. Saxena. 2011. Exploitation of dietary tannins to improve rumen metabolism and ruminant nutrition. J. Sci. Food Agric. 91:24-37.

Reed, J. D. 1995. Nutritional toxicology of tannins and related polyphenols in forages legumes. J. Anim. Sci. 73:1516-1528.

SAS Institute. 1999. SAS User's Guide: Statistics. Version 8.0 ed. SAS Institute Inc., Cary, NC.

Shingfield, K. J., M. Bonnet, and N. D. Scollan. 2013. Recent developments in altering the fatty acid composition of ruminant-derived foods. Animal 7:132-162.

Shook, G. E. 1993. Genetic improvement of mastitis through selection on somatic cell count. Vet. Clin. North Am. Food Anim. Pract. 9:563-581.

Simon, P. 2003. Q-Gene: Processing quantitative real-time RT-PCR data. Bioinformatics 19:1439-1440.

Stevenson, D. M., and P. J. Weimer. 2007. Dominance of Prevotella and low abundance of classical ruminal bacterial species in the bovine rumen revealed by relative quantification real-time PCR. Appl. Microbiol. Biotechnol. 75:165-174.

Terrill, T. H., G. C. Waghorn, D. J. Woolley, W. C. McNabb, and T. N Barry. 1994. Assay and digestion of ${ }^{14} \mathrm{C}$-labelled condensed tannins in the gastrointestinal tract of sheep. Br. J. Nutr. 72:467-477.

Toral, P., G. Hervàs, E. Bichi, A. Belenguer, and P. Fruitos. 2011. Tannins as feed additives to modulate ruminal biohydrogenation: Effects on animal performance, milk fatty acid composition and ruminal fermentation in dairy ewes fed a diet containing sunflower oil. Anim. Feed Sci. Technol. 164:199-206.

Toral, P. G., G. Hervàs, E. Bichi, A. Belenguer, and P. Fruitos. 2013. Effect of the inclusion of quebracho tannins in diet rich in linoleic acid on milk fatty acid composition in dairy ewes. J. Dairy Sci 96:431-439.

Van Soest, P. J., J. B. Robertson, and B. A. Lewis. 1991. Methods for dietary fiber, neutral detergent fiber, and no starch polysaccharides in relation to animal nutrition. J. Dairy Sci. 74:3583-3597.

Vasta, V., and G. Luciano. 2011. The effect of dietary consumption of plants secondary compounds on small ruminants' product quality. Small Rumin. Res. 101:150-159.

Vasta, V., M. Mele, A. Serra, M. Scerra, G. Luciano, M. Lanza, and A. Priolo. 2009a. Metabolic fate of fatty acids involved in ruminal biohydrogenation in sheep fed concentrate or herbage with or without tannins. J. Anim. Sci. 87:2674-2684.

Vasta, V., A. Priolo, M. Scerra, K. G. Hallett, J. D. Wood, and O. Doran. 2009b. $\Delta^{9}$-desaturase protein expression and fatty acid composition of longissimus dorsi muscle in lambs fed green herbage or concentrate with or without added tannins. Meat Sci. 82:357-364.

Vasta, V., D. R. Yanez-Ruiz, M. Mele, A. Serra, G. Luciano, M. Lanza, L. Biondi, and A. Priolo. 2010. Bacterial and protozoal communities and fatty acid profile in the rumen of sheep fed a diet containing added tannins. Appl. Environ. Microbiol. 76:2549-2555.

Vlaeminck, B., V. Fievez, S. Tamminga, R. J. Dewhurst, A. van Vuuren, D. De Brabander, and D. Demeyer. 2006. Milk odd and branched chain fatty acids in relation to the rumen fermentation pattern. J. Dairy Sci. 89:3954-3964.

Waghorn, G. 2008. Beneficial and detrimental effects of dietary condensed tannins for sustainable sheep and goat production-Progress and challenges. Anim. Feed Sci. Technol. 147:116-139.

Zannoni, M., and S. Annibaldi. 1981. Standardization of the rennet ability of milk by Formagraph-I. Sci. Tecn. Latt. Cas. 32:79-94. 